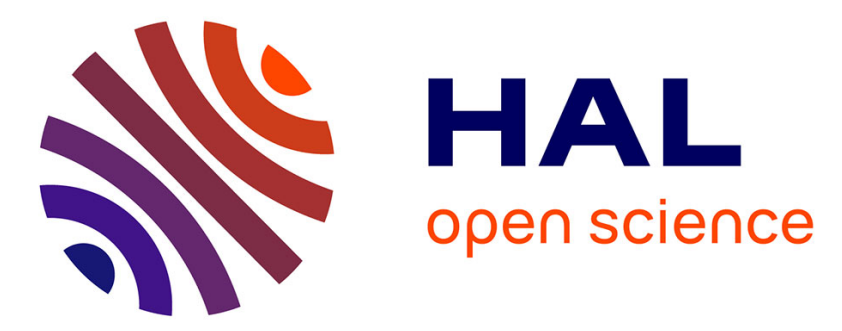

\title{
UVA-induced cyclobutane pyrimidine dimers in DNA: a direct photochemical mechanism?
}

S. Mouret, C. Philippe, J. Gracia-Chantegrel, A. Banyasz, S. Karpati, D. Markovitsi, Thierry Douki

\section{- To cite this version:}

S. Mouret, C. Philippe, J. Gracia-Chantegrel, A. Banyasz, S. Karpati, et al.. UVA-induced cyclobutane pyrimidine dimers in DNA: a direct photochemical mechanism?. Organic \& Biomolecular Chemistry, 2010, 8, pp.1706-1711. 10.1039/b924712b . hal-00472822

\section{HAL Id: hal-00472822 \\ https://hal.science/hal-00472822}

Submitted on 13 Apr 2010

HAL is a multi-disciplinary open access archive for the deposit and dissemination of scientific research documents, whether they are published or not. The documents may come from teaching and research institutions in France or abroad, or from public or private research centers.
L'archive ouverte pluridisciplinaire HAL, est destinée au dépôt et à la diffusion de documents scientifiques de niveau recherche, publiés ou non, émanant des établissements d'enseignement et de recherche français ou étrangers, des laboratoires publics ou privés. 


\title{
UVA-induced cyclobutane pyrimidine dimers in DNA: a direct photochemical mechanism?
}

\author{
Stéphane Mouret ${ }^{\mathrm{a}}$, Coralie Philippe ${ }^{\mathrm{a}}$, Jocelyne Gracia-Chantegrel ${ }^{\mathrm{a}}$, Akos Banyasz ${ }^{\mathrm{b}}$, Szilvia \\ Karpati $^{\mathrm{b}}$, Dimitra Markovitsi ${ }^{\mathrm{b}}$ and Thierry Douki ${ }^{\mathrm{a}^{*}}$
}

\author{
Received (in $X X X, X X X)$ Xth $X X X X X X X X X 200 X$, Accepted $X$ th $X X X X X X X X X 200 X$ \\ First published on the web $X$ th $X X X X X X X X X 200 X$ \\ DOI: 10.1039/b000000x
}

The carcinogenic action of UVA radiation is commonly attributed to DNA oxidation mediated by endogenous photosensitisers. Yet, it was recently shown that cyclobutane pyrimidine dimers (CPD), well known for their involvement in UVB genotoxicity, are produced in larger yield than oxidative lesions in UVA-irradiated cells and skin. In the present work, we gathered mechanistic information on this photoreaction by comparing formation of all possible bipyrimidine photoproducts upon UVA irradiation of cells, purified genomic DNA and $\mathrm{dA}_{20}: \mathrm{dT}_{20}$ oligonucleotide duplex. We observed that the distribution of photoproducts, characterized by the sole formation of CPD and the absence of (6-4) photoproducts was similar in the three types of samples. The CPD involving two thymines represented $90 \%$ of the amount of photoproducts. Moreover, the yields of formation of the DNA lesions were similar in cells and isolated DNA. In addition, the effect of the wavelength of the incident photons was found to be the same in isolated DNA and cells. This set of data shows that UVA-induced cyclobutane pyrimidine dimers are formed via a direct photochemical mechanism, without mediation of a cellular photosensitiser. This is possible because the double-stranded structure increases the capacity of DNA bases to absorb UVA photons, as evidenced in the case of the oligomer $\mathrm{dA}_{20}: \mathrm{dT}_{20}$. These results emphasize the need to consider UVA in the carcinogenic effects of sunlight. An efficient photoprotection is needed that can only be complete by completely blocking incident photons, rather than by systemic approaches such as antioxidant supplementation.

\section{Introduction}

The recent classification of sunbeds as carcinogenic to humans by the International Agency of Research on Cancer ${ }^{1}$ has emphasised the deleterious effects of UVA radiation (320-400 nm). Although less harmful than the more energetic UVB $(280-320 \mathrm{~nm})$, UVA is at least 20 times more abundant in natural sunlight and its involvement in the induction of skin cancer has been put forward for several years ${ }^{2,}{ }^{3}$. Indeed, UVA induces damage to the genome of cells. Oxidative damage, including oxidised bases, strand breaks and DNA-protein crosslinks, has been long believed to be the main type of UVA-mediated DNA lesions ${ }^{4}$. However, cyclobutane pyrimidine dimers (CPDs) (Scheme 1) were found to be produced in larger amounts than oxidative lesions in both cultured cells and whole skin ${ }^{5-10}$. CPDs are well known lesions in photobiology because they are responsible for the mutagenic properties of UVB ${ }^{11}$. The significant formation of this type of damage upon exposure to UVA has opened a new field of investigation. Accordingly, recent mutagenesis studies have shown that mutational events related to the presence of CPDs are frequent in UVA irradiated cells ${ }^{12,13}$. The UVAinduced formation of CPDs is thus now well established and needs to be taken into account in human photoprotection.

Yet, the underlying photochemical mechanism remains to be established. A key question is whether formation of CPDs occurs directly upon absorption of UVA by DNA, as in the case of UVB, or involves mediation of other molecules (photosensitisers). It is indeed known that some compounds, when in their triplet excited state, may transfer the energy to thymine in DNA and promote formation of CPDs ${ }^{14} 15$, 16. In contrast to DNA, whose UV spectrum peaks at $260 \mathrm{~nm}$, photosensitisers may absorb photons of longer wavelength, where sunlight is more intense. The fact that different distributions of photoproducts were determined following irradiation of cells with UVA or UVB is in favour of a photosensitised process. Yet, CPD formation upon UVA irradiation of isolated DNA, e.g. in the absence of cellular photosensitisers, was reported ${ }^{17-20}$. A limitation of these studies is that they are based on biochemical approaches that do not allow an extensive description of the distribution of all bipyrimidine photoproducts. In particular no information is available on the formation of pyrimidine (6-4) pyrimidone photoproducts (64PPs), the second major class of lesions formed upon direct excitation by UVB or UVC photons. In addition, biochemical tools do not provide information on the relative formation of the different CPDs and 64PPs, namely those involving two 
thymines (TT), one thymine and one cytosine (TC and CT) or two cytosines (CC).

The objective of the present work was to elucidate the mechanism of formation of UVA-induced CPDs. The basic idea was to compare the distribution of DNA damage in cells and in isolated DNA. Major contribution of endogenous photosensitisers should lead to a difference between the two sets of data. For this purpose, the eight possible DNA dimeric photoproducts were quantified by HPLC-coupled to tandem mass spectrometry. Dewar valence isomers, photolysis products of 64PPs, were also searched. It should be emphasised that the chemical purity of isolated DNA as well as the spectral purity of the radiation are key factors for the reliability of the results. These points were addressed by the use of both purified commercially available isolated DNA and oligonucleotides of purely synthetic origin. The question of the source of radiation was addressed through the use of a set of filters and of a comparison between the effects of broad- and narrowband UVA. By strictly controlling these factors, the present work provides clear evidence that CPDs are actually produced by UVA through a direct photochemical process.

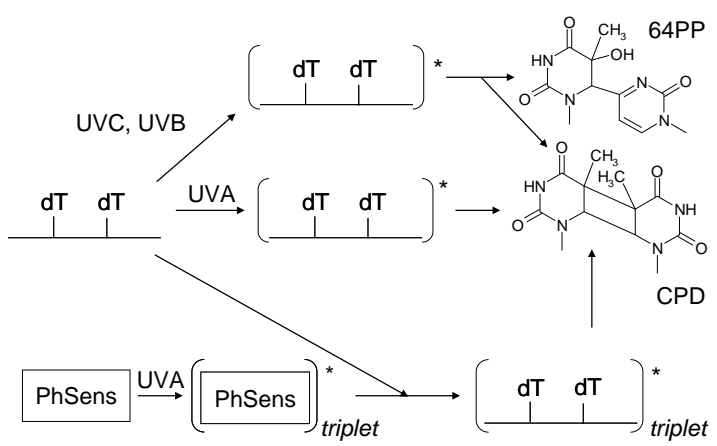

Scheme 1: Thymine (dT) photoproducts formed upon exposure to UV radiation. UVC and UVB photons are absorbed by DNA and lead to the formation of both CPDs and 64PP. Only CPDs are produced by UVA radiation possibly through i) a direct mechanism involving excited states that remain to be characterised or ii) a photosensitised triplet energy transfer involving an unidentified cellular photosensitiser.

\section{Results}

UVA-induced pyrimidine dimers in isolated DNA: effect of purification

A large amount of experiments on isolated DNA was performed with commercially available high grade calf thymus DNA (CT-DNA). Calf thymus DNA was selected among possible easily available sources of isolated DNA because its content in G:C base pairs is similar to that of human and all other mammals. As a preliminary work, the absence of CPDphotosensitizing compounds was checked by purifying CT-DNA prior to irradiation. First, a Chelex ion exchange resin was used in order to remove metal ions. This method was previously shown to be efficient for the removal of iron and copper ${ }^{21}$. A second treatment involved extensive dialysis to remove soluble small contaminants. Last, we used saturated sodium iodide to remove any trace of proteins bound to DNA followed by dialysis. As shown in table 1, none of these treatments had significant effect on the yield of photoproducts upon subsequent exposure to UVA radiation. Anyway, CTDNA samples used in subsequent experiments were all treated by Chelex resin and dialysed before irradiation.

Table 1: Level ${ }^{\mathrm{a}}$ of dimeric photoproducts within DNA exposed to $\mathrm{UVA}^{\mathrm{b}}$ following purification by different techniques.

\begin{tabular}{cc|c|c|c}
\hline treatment & TT CPD & TT 64 & TC CPD & TC 64 \\
\hline $\begin{array}{c}\text { crude } \\
\text { DNA }\end{array}$ & $6.0 \pm 1.0$ & $0.0 \pm 0.0$ & $0.8 \pm 0.1$ & $0.1 \pm 0.0$ \\
\hline $\begin{array}{c}\text { chelex } \\
\text { DNA }\end{array}$ & $5.6 \pm 0.5$ & $0.0 \pm 0.0$ & $0.8 \pm 0.5$ & $0.1 \pm 0.0$ \\
\hline NaI DNA & $6.3 \pm 0.3$ & $0.0 \pm 0.0$ & $1.2 \pm 0.1$ & $0.1 \pm 0.0$ \\
\hline $\begin{array}{c}\text { Dialysed } \\
\text { DNA }\end{array}$ & $6.0 \pm 0.1$ & $0.0 \pm 0.0$ & $1.3 \pm 0.5$ & $0.1 \pm 0.0$ \\
\hline
\end{tabular}

${ }^{a}$ Dimer frequencies are expressed in lesions per $10^{6}$ normal bases. ${ }^{\mathrm{b}}$ The overall fluence was $35 \mathrm{~J} \mathrm{~cm}^{-2}$.

\section{Absorption of $\mathrm{dA}_{20}: \mathrm{dT}_{20}$ in the UVA range}

The absorption spectrum of oligomeric duplex $\mathrm{dA}_{20}: \mathrm{dT}_{20}$ recorded in the $225-400 \mathrm{~nm}$ range is shown in Figure 1. For comparison we also present the spectrum of an equimolar mixture of free nucleosides, thymidine (dT) and 2'-deoxyadenosine (dA). We observe that, only in the case of the duplex, a long tail of weak intensity persists in the UVA range. Around $350 \mathrm{~nm}$, the molar extinction coefficient determined for $\mathrm{dA}_{20:} \mathrm{dT}_{20}$ is higher by at least one order of magnitude than that of the equimolar mixture of nucleosides.

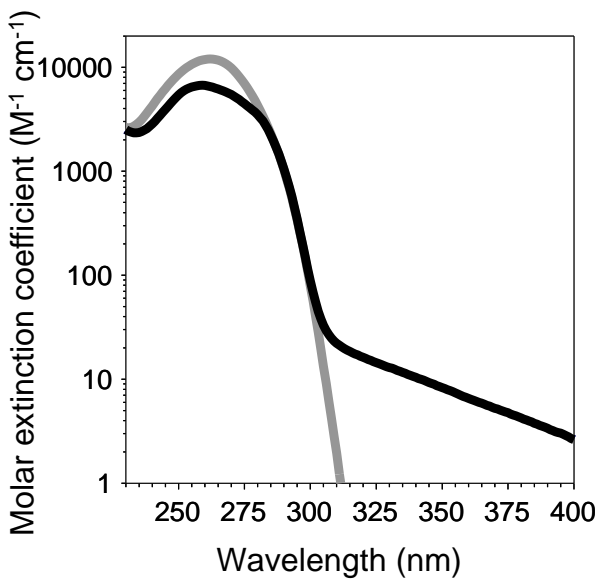

Figure 1: Absorption spectra of the duplex $\mathrm{dA}_{20}: \mathrm{dT}_{20}$ (black) and an equimolar mixture of nucleosides $\mathrm{dA}$ and $\mathrm{dT}$ (grey). The molar extinction coefficient is given per base.

Distribution of pyrimidine dimers within CT-DNA and $\mathrm{dA}_{20}: \mathrm{dT}_{20}$

The level of all possible CPDs and 64PPs was then determined in purified CT-DNA exposed to the 
broadband UVA lamp. A dose dependence formation was observed for TT, TC and CT CPDs. Neither CC CPD, nor 64PPs nor Dewar valence isomers were detected (Fig. 2). The distribution of photoproducts was then determined in CT-DNA samples exposed to radiation emitted by a Xenon Arc passing through a double monochromator $(354 \pm 5 \mathrm{~nm})$. A distribution similar to that obtained with the broadband UVA lamp was observed. In order to further confirm the ability of UVA to induce CPDs in DNA in a cell-free system, we exposed the duplex oligonucleotide $\mathrm{dA}_{20}: \mathrm{dT}_{20}$ to the $354 \mathrm{~nm}$ beam. Again, formation of large amounts of the TT CPD was observed while neither TT 64PP nor its Dewar isomer was detected.

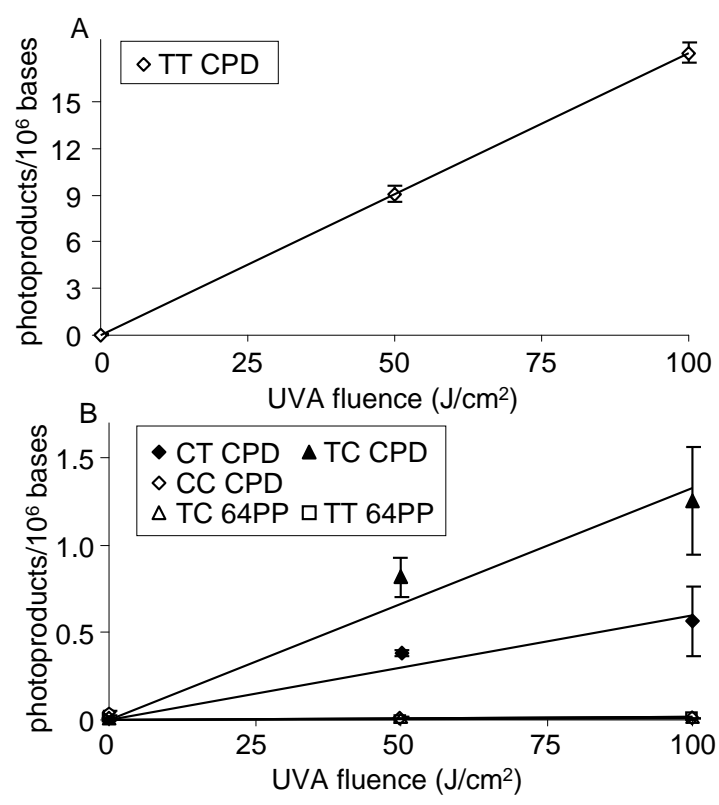

Figure 2: Dose-course formation of pyrimidine dimers within isolated CT-DNA exposed to UVA radiation. A) TT CPD, B) Other CPDs and 64PPs.

\section{Comparison between isolated and cellular DNA}

Primary cultures of human keratinocytes were then exposed to the broadband UVA source. DNA was extracted and the amount of photoproducts was determined. In agreement with our previous observations, only TT, TC and CT CPDs could be detected. The relative distribution was then compared to that obtained for isolated DNA exposed to broadband or monochromatic UVA source (Fig. 3). A very similar profile was obtained in the three cases. It should be noticed that exposure of cells to monochromatic radiation was not possible for technical reasons (geometry of the source, exposure time). Similar results were also obtained in terms of absolute yields of formation. For TT-CPD, it was $0.175 \pm 0.006$ and $0.181 \pm 0.001$ lesions $/ 10^{6}$ bases per $\mathrm{J} \mathrm{cm}^{-2}$ in isolated DNA and cells, respectively.

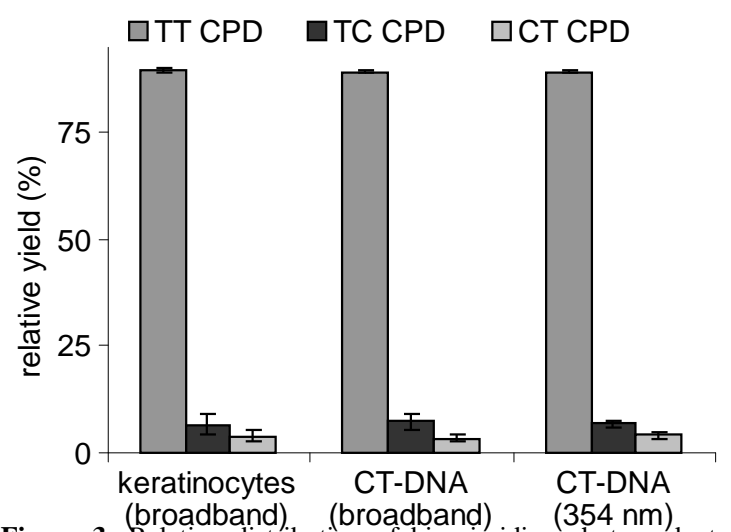

Figure 3: Relative distribution of bipyrimidine photoproducts within isolated DNA and DNA from keratinocytes exposed to UVA radiation. 64PPs, Dewar isomers and CC CPD were not detected.

Effect of GC content on the formation of UVAinduced CPDs in isolated DNA

In order to better delineate the parameters influencing the formation of CPDs upon exposure of isolated DNA to UVA, we irradiated CT-DNA, as well as genomic DNA from Micrococcus luteus and Clostridium perfringens. These three types of DNA were selected because they exhibit very different contents in G:C base pairs, respectively 72,41 and $25 \%$ for M. luteus, $\mathrm{CT}$ and $C$. perfringens, respectively. Exposure to 100 $\mathrm{J} / \mathrm{cm}^{2}$ UVA led to the formation of TT, TC and CT CPDs in different yields depending on the DNA type (Fig. 4). The yields were proportional to the frequency of each of the bipyrimidine dinucleotides. Indeed, the proportion of TT among all possible bipyrimidine dinucleotides is $1.5,9.9$ and $16.5 \%$ for M. luteus, CT and $C$. perfringens DNA, respectively. Similar trends were observed for TC and CT (data not shown).

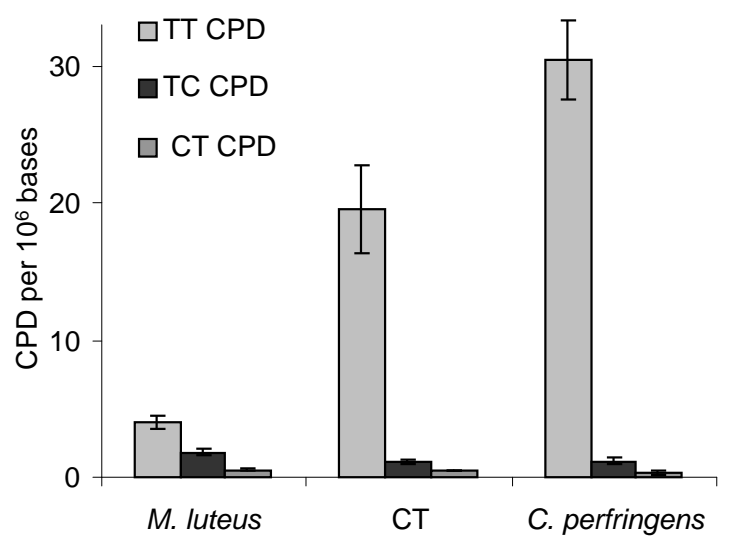

Figure 4: Level of TT, TC and CT CPDs in isolated DNA from $M$. luteus, CT and C. perfringens exposed to $100 \mathrm{~J} / \mathrm{cm}^{2} \mathrm{UVA}$ radiation. 64PPs, Dewar isomers and CC CPD were not detected.

\section{Wavelength effect on the yield of UVA-induced CPDs}

In a subsequent step, the effect of the wavelength of the incident photons on the formation of the CPDs in isolated and cellular DNA was studied. For this purpose, a set of filters with increasing cut-off wavelength (50\% transmittance) were placed between 
the broadband lamp and the sample (Fig. 5).

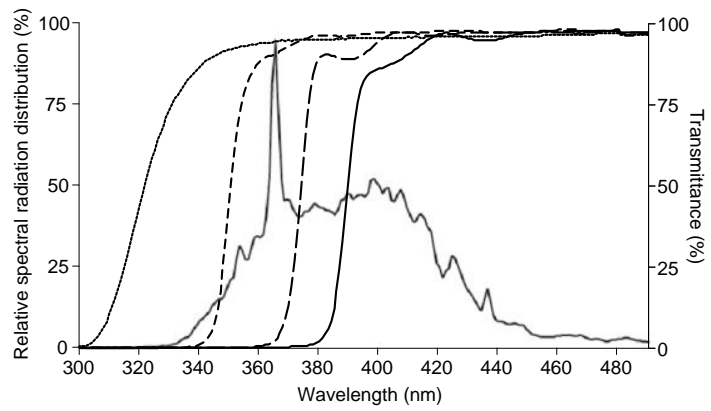

Figure 5: Emission spectrum of the broadband UVA lamp and transmittance of the four filters with increasing cut-off wavelength.

As shown in Table 2 for TT CPD, addition of a filter did not significantly modify the yield of photoproducts. The yield remained in the same range even when only UVA photons with the lowest energy reached DNA or cells. The increase observed for the $390 \mathrm{~nm}$ filter could be explained by a lower accuracy of the dosimetry due to the low value of the fluence rate to measure. In addition to the absolute yields, the distribution also remained unchanged when filters were used. The average proportions of TT, TC and CT CPDs were $89.3 \pm 1.5,7.2 \pm 1.4$ and $3.5 \pm 0.5 \%$, respectively in CT-DNA. The corresponding values were $89.4 \pm 0.8,6.7 \pm 0.5$ and $3.9 \pm 0.5 \%$ in keratinocytes.

Table 2: Yield ${ }^{\text {a }}$ of TT CPD within CT-DNA and keratinocytes exposed to UVA through filters exhibiting increasing cut-off wavelength ${ }^{\mathrm{b}}$.

\begin{tabular}{c|cc}
\hline Cut-off $\lambda^{b}$ & CT-DNA & Keratinocytes \\
\hline 322 & $0.188 \pm 0.008$ & $0.197 \pm 0.003$ \\
\hline 351 & $0.168 \pm 0.008$ & $0.205 \pm 0.011$ \\
\hline 374 & $0.151 \pm 0.007$ & $0.204 \pm 0.006$ \\
\hline 390 & $0.246 \pm 0.009$ & $0.233 \pm 0.007$ \\
\hline
\end{tabular}

${ }^{a}$ Dimer yields are expressed in lesions $/ 10^{6}$ bases per $\mathrm{J} \mathrm{cm}^{-2}$. ${ }^{\mathrm{b}}$ Wavelengths are expressed in $\mathrm{nm}$.

\section{Discussion}

UVA-induced formation of CPDs in cells and skin has emerged in the recent years as a new genotoxic pathway to consider in order to fully understand the carcinogenic effects of solar radiation. Surprisingly, this photoreaction is well established in cells but basic mechanistic studies remain limited. In particular, it is not known whether a photosensitised or a direct mechanism is involved. The few reports on the formation of CPDs within isolated DNA suggest that the latter pathway could be possible.

Using a state-of-the-art chromatographic analytic approach for DNA photoproducts, we first confirmed these previous data obtained by biochemical techniques. Furthermore, we tried to unravel any major role played by a contaminant that could act as photosensitiser for triplet energy transfer. We found that application of several purification techniques to CT-DNA did not affect the formation of CPDs upon exposure to UVA. Formation of CPDs was also observed in UVA-irradiated synthetic $\mathrm{dA}_{20}: \mathrm{dT}_{20}$. This observation is further evidence that the UVA-induced formation of CPD in isolated CT-DNA is not an artifact resulting from the presence of impurities. Indeed, while CT-DNA may be potentially contaminated by cellular components, this is not possible for $\mathrm{dA}_{20}: \mathrm{dT}_{20}$ that is of chemical origin.

The $\mathrm{dA}_{20}: \mathrm{dT}_{20}$ oligonucleotide was chosen as a model duplex because UVA irradiation of cellular DNA leads mainly to TT cyclobutane dimers $5,7,8$. In addition, large amounts of information are available on the excited states of this type of probes ${ }^{22-27}$. Another interesting aspect is that accurate absorption spectra can be recorded on this model system. Indeed, it is important to show that DNA exhibits significant absorption in the UVA range before investigating the possibility of a direct mechanism. It was reported previously that genomic DNA exhibits a weak absorbance at wavelengths longer than $300 \mathrm{~nm}{ }^{28}$ but this property was correlated with the content in G:C base pairs. The present results show that the duplex $\mathrm{dA}_{20}: \mathrm{dT}_{20}$, composed solely of A:T base pairs, also exhibits weak, albeit detectable, absorption in the UVA domain.

It should be emphasised that, in contrast to genomic DNA used in the previous study, oligonucleotides are small objects compared to the wavelength and do not give rise to light scattering which interferes with weak absorption signals. Therefore, it was possible to determine the molar absorption coefficients corresponding to the duplex which are clearly higher than those of the constitutive monomeric nucleosides $\mathrm{dA}$ and $\mathrm{dT}$ in the UVA spectral domain. This is explained by the collective behaviour of the DNA bases within the helix governed by the electronic coupling ${ }^{29}$. In other terms, the excited states populated by photon absorption may be delocalised over a few bases (excitons). The excitation energy of the exciton states is different than those of the monomeric units, some of them being located at lower energies (longer wavelengths) ${ }^{30,31}$.

The capacity of duplex DNA to absorb UVA photons as well as observation of the CPDs formation in isolated DNA are not enough to conclude that the same mechanism is valid in the case of cells. Additional evidence was first gathered from the distribution of the photoproducts. We found that CPDs were produced in isolated DNA with a large predominance of the thymine-thymine derivative. TC and CT CPDs were produced in a ten-fold lower yield while CC CPD was not detected. In addition, 64PPs, another major class of dimeric DNA photoproducts, were not observed. The absence of Dewar valence 
isomers, that were found to be readily produced from 64PPs upon UVA irradiation ${ }^{7}, 10,32$, was checked. Formation of only CPDs and not of 64PPs was also found for the synthetic duplex $\mathrm{dA}_{20}: \mathrm{dT}_{20}$. The same distribution of photoproducts was observed in UVAirradiated human keratinocytes, in agreement with our previous observations, and was similar to that made in whole skin ${ }^{7,8}$. It is worth mentioning that the yield of TT CPD is very close in CT-DNA and in cells. No rigorous comparison is possible because absorption of UVA photons by cellular DNA is not known, but this observation suggests the absence of major photosensitization processes that would greatly promote formation of CPDs in cells.

Another interesting observation is that GC content of DNA exhibits an effect similar to that previously observed with $\mathrm{UVB}^{33}$. Indeed, TT, TC and CT CPDs are produced in significant amounts in DNA with GC content ranging from 25 to $72 \%$ but the relative contribution of each photoproduct is proportional to that of the considered dinucleotide (more TT sites at low GC content). This observation is an interesting similarity between UVA induced formation CPDs and direct UVB photochemistry of DNA. In addition, these results show that our observations made on mammalian cells could be extended to other species. These observations also emphasize that UVA can damage DNA independently of the proportion of guanine, as discussed above for the absorption.

In a subsequent step, the effect of the energy of the incident photons on the formation of the CPDs in isolated and cellular DNA was compared. For this purpose, a set of filters exhibiting increasing cut-off wavelength was used. Again, identical trends were observed for human primary keratinocytes and DNA solutions. The application of these filters did not significantly affect either the yield of various CPDs or their relative distribution. The strong similarities in the formation of pyrimidine dimers with regard to the wavelength in isolated and cellular DNA further supported that the same direct mechanism was involved in cells like in isolated DNA. Moreover, if a photosensitiser was involved, important wavelength dependence in the UVA region should be observed, as reported for oxidative lesions 34, 35. Additional information obtained from these experiments is that the formation of CPDs cannot be explained by the presence of traces of UVB radiation in the broadband UVA radiation. This is confirmed by the observation that the same distribution of photoproducts was obtained for isolated DNA whether the radiation used was produced by the UVA lamp or the Xenon Arc passing through a double monochromator.

\section{Conclusion}

In summary, the present data show that the formation of CPDs in cells and isolated DNA share strong similarities in terms of i) efficiency, ii) distribution of photoproducts and iii) modulation by the wavelength of the incident photons. The photoreaction is thus likely to occur though the same mechanism under both conditions. In addition, purification experiments and comparison between isolated genomic DNA and oligonucleotides show that no cellular photosensitiser is involved. Last, duplex DNA composed of thymine tracts is capable of absorbing UVA radiation. The ensemble of these observations allows us to conclude that UVA-induced formation of CPDs is most likely a direct mechanism. These results may have consequences in terms of human photoprotection. Based on the assumption that UVA mostly damages DNA through oxidative stress, systemic approaches involving antioxidant supplementation have been proposed. However, such a strategy does not take into account the intrinsic vulnerability of DNA towards UVA established in the present work. Rather, an efficient photoprotection against the carcinogenic effects of solar UVA radiation requires complete blocking of the incident photons.

\section{Experimental}

\section{Chemicals}

The oligomer $\mathrm{dA}_{20}: \mathrm{dT}_{20}$ was obtained from Eurogentec and purified by PAGE. Isolated calf thymus DNA (type I, highly polymerised), Micrococcus luteus DNA, Clostridium perfringens DNA, Sodium chloride, phosphodiesterase I, phosphodiesterase II and nuclease P1 were purchased from Sigma (St Louis, MO). Alkaline phosphatase was obtained from Roche Diagnostics (Manheim, Germany). Calibrated solutions of the CPD, 64PP and Dewar isomer of thymidylyl (3'-5') thymidine, thymidylyl (3'-5') 2' deoxycytidine, $2^{\prime}$ deoxycytidylyl $\left(3^{\prime}-5^{\prime}\right)$ thymidine and 2 ' deoxycytidylyl (3'-5') 2' deoxycytidine were prepared as previously reported 36,37 .

\section{DNA samples preparation}

A $1.2 \mathrm{mg} / \mathrm{mL}$ solution of the crude product in water was prepared. For the comparison of purification procedures, a first sample was only diluted in water to reach a concentration of $0.5 \mathrm{mg} \mathrm{mL}^{-1}$ controlled by UV absorption. $\mathrm{NaCl}$ was added to reach a concentration of $50 \mathrm{mM}$. Another aliquot fraction of the crude solution was mixed with Chelex resin, vortexed and centrifuged. The supernatant was collected and used to prepare a $0.5 \mathrm{mg} \mathrm{ml}^{-1}$ solution in $50 \mathrm{mM} \mathrm{NaCl}$. A third fraction of crude solution was placed in dialysis cassettes (Slide-A-Lyzer, Thermo Scientific, cut-off molecular weight 10,000). The solution was then dialysed overnight in three successive bathes of MilliQ water for 2, 6 and $16 \mathrm{~h}$. The solution was recovered, calibrated by UV measurement and adjusted to $0.5 \mathrm{mg} \mathrm{mL}^{-1}$ in $50 \mathrm{mM}$ $\mathrm{NaCl}$. For the fourth sample, the crude solution was mixed with an equal volume of a saturated aqueous solution of sodium iodide (7.6 M NaI, $40 \mathrm{mM}$ TRIS, $20 \mathrm{mM}$ EDTA, pH 8) and incubated for $1 \mathrm{~h}$ at room temperature. Dialysis was then performed as described above with an additional $24 \mathrm{~h}$ step. In all the other 
experiments involving CT-DNA, the crude solution was treated with Chelex resin, dialysed in 3 bathes for an overall $24 \mathrm{~h}$ period, and DNA was diluted to obtain a $0.7 \mathrm{mg} \mathrm{mL}$ solution in $50 \mathrm{mM} \mathrm{NaCl}$. For experiments on the effect of GC content, samples were prepared as described above with a final dialysis step of $6 \mathrm{~h}$ with the three cassettes, containing DNA from either calf thymus, Micrococcus luteus or Clostridium perfringens, placed in the same water bath. The dinucleotides frequencies of these types of DNA were taken from Matallana-Surget et al. ${ }^{33}$

\section{Absorption spectra}

Steady-state absorption spectra were recorded with a Perkin Lamda 900 spectrophotometer using $10 \mathrm{~mm}$ quartz cells (QZS). The absorption spectra were reconstructed as follows. First the 290-500 nm part of the spectrum was recorded with a solution of high concentration, and then it was precisely diluted to record the peak of high absorbance between 220$300 \mathrm{~nm}$. By knowing the dilution factor the two spectra were joined. Different dilution factors, ranging from 1 to 15 , gave the same result with an error $\pm 30 \%$. The maximum molar extinction coefficient of $\mathrm{dA}_{20}: \mathrm{dT}_{20}$ was taken from Banyasz et al. ${ }^{38}$

\section{Cell culture}

Human keratinocytes were isolated from skin explants obtained after breast plastic surgery from healthy Caucasian donors with their inform consent (Department of "Chirurgie Plastique et Maxillofaciale", CHU Grenoble, France). Cells were grown in serum free keratinocyte growth medium (Invitrogen, France) supplemented with recombinant epidermal growth factor, bovine pituitary extract and primocin (Cayla-Invivogen, France). Keratinocytes were grown to subconfluence in $60 \mathrm{~mm}$ Petri dish. Just before irradiation, culture medium was removed and cells were irradiated through PBS on ice. Immediately after treatment, keratinocytes were trypsinised and recovered by centrifugation. The subsequent DNA extraction protocol involved first lysis of the plasma membrane and isolation of the nuclei. Those were then lysed by addition of SDS and treated by RNase and protease. DNA was precipitated by addition of sodium iodide and 2-propanol.

\section{Irradiations}

Irradiation of isolated DNA samples and human primary culture of keratinocytes with broadband UVA was carried out with a UVA 700L Waldmann lamp. Samples were kept on ice. The fluence rate was determined, when necessary through the filters, by using the probe provided with the lamp by the manufacturer. Fluences of 50 and $100 \mathrm{~J} \mathrm{~cm}^{-2}$ were applied. Irradiations were performed in triplicates. Some irradiations were performed through filters provided by Schott. Those were either a WG320 filter or coated derivatives exhibiting different cut-off wavelength (50\% transmittance). The latter value was accurately determined with a UV-visible spectrophotometer. Irradiations of CT-DNA and oligonucleotides at $354 \mathrm{~nm}$ were carried out in a Fluorolog-3 spectrofluorimeter, equipped with a double monochromator (bandwidth: $10 \mathrm{~nm}$ ). In order to avoid the formation of high local concentration of photoproducts, solutions were mildly stirred by a Teflon-coated magnetic stirrer. During the irradiation the temperature was kept at $23 \pm 0.1^{\circ} \mathrm{C}$ by a Huber CC3 apparatus. The overall applied fluence was approximately $2000 \mathrm{~J} \mathrm{~cm}^{-2}$.

\section{Quantification of bipyrimidine photoproducts}

DNA samples were hydrolysed by incubation with nuclease P1, phosphodiesterase II, DNase II, phosphodiesterase I and alkaline phosphatase. Normal bases were thus released as nucleosides while dimeric photoproducts were recovered as dinucleoside monophosphates. Samples were then analysed by HPLC associated to mass spectrometry with negative electrospray ionization. For this purpose, an SCIEX API 3000 electrospray triple quadrupolar spectrometer was used in association with a series 1100 Agilent chromatographic system. The column used was an octadecylsilyl silica gel column Uptisphere ODB $(15 \times 2 \mathrm{~mm}, 3 \mu \mathrm{m}$ particle size, Interchim, Montluçon France). Analyses were performed in the gradient mode with increasing proportion of acetonitrile (maximum $10 \%$ ) in $2 \mathrm{mM}$ triethylammonium acetate (pH 6.3). Sensitive and specific multiple reaction monitoring mode was used to individually quantify all possible thymine and/or cytosine CPDs and 64PPs ${ }^{36,}$ 37. Yields of formation were calculated by linear regression of the dose-course curves. Errors are the standard errors of the slope. Relative distributions were calculated by summing the level of all bipyrimidine photoproducts for a given sample and percentages of the amount of each photoproduct was summarized. Results obtained for different fluences were then summarized for a defined irradiation condition (filter, GC content, etc.).

\section{Notes \\ ${ }^{a}$ DSM/INAC/SCIB UMR-E 3 CEA/UJF FRE CNRS \\ 3200/Laboratoire "Lésions des Acides Nucléiques", CEA- \\ Grenoble; France Fax: (33) 4387850 90; Tel: (33) 4387831 91; e-mail: thierry.douki@cea.fr \\ ${ }^{b}$ Laboratoire Francis Perrin, DSM/IRAMIS/SPAM - CNRS URA 2453, CEA-Saclay, France}

\section{Acknowledgement:}

This work was supported by a grant from the French "Agence National pour la Recherche" (ANR-07-PCVI-0004-01). The authors wish to thank Prof. M. T. Leccia and the surgeons of the Grenoble Hospital for making skin explants available.

\section{References}

1. F. El Ghissassi, R. Baan, K. Straif, Y. Grosse, B. Secretan, V. Bouvard, L. Benbrahim-Tallaa, N. Guha, C. Freeman, L. 
Galichet and V. Cogliano, Lancet Oncol., 2009, 10, 751752.

2. E. A. Drobetsky, J. Turcotte and A. Chateauneuf, Proc. Natl. Acad. Sci. USA, 1995, 92, 2350-2354.

3. A. Stary, C. Robert and A. Sarasin, Mutat. Res., 1997, 383, $1-8$

4. J. Cadet, T. Douki, J. L. Ravanat and P. Di Mascio, Photochem. Photobiol. Sci., 2009, 8, 903-911.

5. S. Courdavault, C. Baudouin, M. Charveron, A. Favier, J. Cadet and T. Douki, Mutat. Res., 2004, 556, 135-142.

6. R. M. Tyrrell, Photochem. Photobiol., 1973, 17, 69-73.

7. T. Douki, A. Reynaud-Angelin, J. Cadet and E. Sage, Biochemistry, 2003, 42, 9221-9226.

8. S. Mouret, C. Baudouin, M. Charveron, A. Favier, J. Cadet and T. Douki, Proc. Natl. Acad. Sci. USA, 2006, 103, $13765-13770$.

9. A. R. Young, C. A. Chadwick, G. I. Harrison, O. Nikaido, J. Ramsden and C. S. Potten, J. Invest. Dermtol., 1998, 111, 982-928.

10. D. Perdiz, P. Grof, M. Mezzina, O. Nikaido, E. Moustacchi and E. Sage, J. Biol. Chem., 2000, 275, 26732-26742.

11. Y. H. You, D. H. Lee, J. H. Yoon, S. Nakajima, A. Yasui and G. P. Pfeifer, J. Biol. Chem., 2001, 276, 44688-44694.

12. U. P. Kappes, D. Luo, M. Potter, K. Schulmeister and T. M. Rünger, J. Invest. Dermtol., 2006, 126, 667-675.

13. P. J. Rochette, J.-P. Therrien, R. Drouin, D. Perdiz, N. Bastien, E. A. Drobetsky and E. Sage, Nucleic Acids Res., 2003, 31, 2786-2794.

14. F. Bosca, V. Lhiaubet-Vallet, M. C. Cuquerella, J. V. Castell and M. A. Miranda, J. Am. Chem. Soc., 2006, 128, 6318-6319.

15. V. Lhiaubet-Vallett, J. Trzcionka, S. Encinas, M. A. Miranda and N. Chouini-Lalanne, J. Phys. Chem. B, 2004, 108, 14148-14153.

16. I. G. Gut, P. D. Wood and R. W. Redmond, J. Am. Chem. Soc., 1996, 118, 2366-2373.

17. F. E. Quaite, B. M. Sutherland and J. C. Sutherland, Nature, 1992, 358, 576-578.

18. X. S. Zhang, B. S. Rosenstein, Y. Wang, M. Lebwohl, D. M. Mitchell and H. C. Wei, Photochem. Photobiol., 1997, $65,119-124$.

19. Y. Jiang, M. Rabbi, M. Kim, C. H. Ke, W. Lee, R. L. Clark, P. A. Mieczkowski and P. E. Marszalek, Biophys. J., 2009, 96, 1151-1158.

20. A. P. Schuch, R. D. Galhardo, K. M. de Lima-Bessa, N. J. Schuch and C. F. M. Menck, Photochem. Photobiol. Sci., 2009, 8, 111-120.

21. S. Frelon, T. Douki, A. Favier and J. Cadet, J. Chem. Soc. Perkin Trans. 1, 2002, 2866-2870.

22. D. Markovitsi, T. Gustavsson and F. Talbot, Photochem. Photobiol. Sci., 2007, 6, 717-724.

23. C. E. Crespo-Hernandez, B. Cohen and B. Kohler, Nature, 2005, 436, 1141-1144.

24. D. Markovitsi, F. Talbot, T. Gustavsson, D. Onidas, E. Lazzarotto and S. Marguet, Nature, 2006, 441, E7; discussion E8

25. I. Buchvarov, Q. Wang, M. Raytchev, A. Trifonov and T. Fiebig, Proc. Natl. Acad. Sci. USA, 2007, 104, 4794-4797.

26. D. Markovitsi, A. Sharonov, D. Onidas and T. Gustavsson, Chemphyschem, 2003, 4, 303-305.

27. F. Santoro, V. Barone and R. Improta, Chemphyschem, 2008, 9, 2531-2537.

28. J. C. Sutherland and K. P. Griffin, Radiat. Res., 1981, 86, 399-409.

29. D. Markovitsi, D. Onidas, T. Gustavsson, F. Talbot and E. Lazzarotto, J. Am. Chem. Soc., 2005, 127, 17130-17131.

30. A. W. Lange and J. M. Herbert, J. Am. Chem. Soc., 2009, 131, 3913-3922.

31. F. Santoro, V. Barone and R. Improta, J. Am. Chem. Soc., $2009,131,15232-15245$

32. S. Courdavault, C. Baudouin, M. Charveron, B. Canghilem, A. Favier, J. Cadet and T. Douki, DNA Repair, 2005, 4, $836-844$.
33. S. Matallana-Surget, J. A. Meador, F. Joux and T. Douki, Photochem. Photobiol. Sci., 2008, 7, 794-801.

34. C. Kielbassa, L. Roza and B. Epe, Carcinogenesis, 1997, 18, 811-816

35. E. Kvam and R. M. Tyrrell, Carcinogenesis, 1997, 18, 2281 2283.

36. T. Douki, M. Court, S. Sauvaigo, F. Odin and J. Cadet, J. Biol. Chem., 2000, 275, 11678-11685.

37. T. Douki and J. Cadet, Biochemistry, 2001, 40, 2495-2501.

38. A. Banyasz, S. Karpati, E. Lazzarotto, D. Markovitsi and T. Douki, J. Phys. Chem. C, 2009, 113, 11747-11750. 
Graphical content entry 